\title{
Streamflow Changes of Small and Large Rivers in the Aldan River Basin, Eastern Siberia
}

\author{
Liudmila Lebedeva ${ }^{1, *(D)}$ and David Gustafsson ${ }^{2}$ \\ 1 Melnikov Permafrost Institute Siberian Branch of the Russian Academy of Sciences, 677010 Yakutsk, Russia \\ 2 Swedish Meteorological and Hydrological Institute, SE-601 76 Norrkoping, Sweden; \\ david.gustafsson@smhi.se \\ * Correspondence: lyudmilaslebedeva@gmail.com
}

check for

updates

Citation: Lebedeva, L.; Gustafsson, D. Streamflow Changes of Small and Large Rivers in the Aldan River Basin, Eastern Siberia. Water 2021, 13, 2747. https://doi.org/10.3390/w13192747

Academic Editor: Yaning Chen

Received: 23 August 2021

Accepted: 1 October 2021

Published: 3 October 2021

Publisher's Note: MDPI stays neutral with regard to jurisdictional claims in published maps and institutional affiliations.

Copyright: (c) 2021 by the authors. Licensee MDPI, Basel, Switzerland. This article is an open access article distributed under the terms and conditions of the Creative Commons Attribution (CC BY) license (https:// creativecommons.org/licenses/by/ $4.0 /)$.

\begin{abstract}
The flow of large northern rivers has increased, but regional patterns of changes are not well understood. The aim of this study is the estimation of monthly discharge changes of the 11 river catchments in the Aldan River basin in Eastern Siberia, the largest Lena River tributary and the sixth largest river in Russia. We considered the trend dependence on month, number of years in the sample, finish and start years, and basin area. The median fraction of samples with no trend, positive and negative trends are $70.5 \%, 28.5 \%$, and $1 \%$, respectively. Longer samples tend to show more positive trends than shorter ones. There is an increasing fraction of samples with positive trends as a function of later sample end year, whereas the start year does not result in a similar pattern. The larger basins, with one exception, have more positive trends than smaller ones. The trends in monthly streamflow have prominent seasonality with absence of positive trends in June and increasing fraction of samples with positive trends from October till April. The study reports the recent streamflow changes on the rarely analyzed rivers in Eastern Siberia, where air temperature rises faster than in average on the globe. The study results are important for water resources management in the region and better understanding of current environmental changes.
\end{abstract}

Keywords: river streamflow change; Eastern Siberia; trend analysis; permafrost hydrology; Aldan river; climate change

\section{Introduction}

Climate change drives the intensification of the high-latitude water cycle in recent decades. While reported hydrological changes are contradictive in North American rivers [1-6] recent increase of streamflow of the Artic Eurasian Rivers is manifested in many studies [7-9]. The annual flow of Russian Arctic rivers increased by 4-18\% in 1976-2014 in comparison with the period 1936-1975 [10]. Besides annual streamflow increase, runoff seasonality is changing, namely a shift to earlier and more elongated snowmelt spring floods [9,11-15] and increase of the winter flow [16-19]. While the broad-scale pattern of streamflow changes is relatively clear, regional- and local-scale patterns are not well understood [20].

The Lena River is one of the largest Arctic rivers. It contributes 524 cubic $\mathrm{km}$ of freshwater per year, or about $15 \%$ of the total freshwater flow into the Arctic Ocean [21]. Significant change was noted in the annual and seasonal Lena river streamflow [14,15,21-24]. It was attributed to both anthropogenic influence through reservoir construction and natural climatic shift along with related consequences on permafrost degradation, wildfires and landscape transformation.

Most of the existing studies analyze hydrological changes in the Lena river before $2000[7,9,17,18,21-23]$. Some researchers suggest intensification of changes in the 21st century $[15,24,25]$.

Different methods of trend estimation are used in the analysis of hydrological changes. Although the length of the data series largely determines the test result, many studies 
compare the results obtained on a series of different durations $[19,24,26]$ that hampers interpretation and attribution of trends to natural drivers. In this paper, we present trend detection results on multiple samples with variable length, beginning and end years for every studied gauge.

The Mann-Kendall test and its modifications are frequently applied for trend analysis, since it is robust to non-normality of the underlying data [2]. Nevertheless, initial data series need to be checked against jumps/breakpoints and data gaps before it can be applied successfully [27].

Most of the Arctic streamflow change studies consider only outlets of large rivers, including the Lena River. Only a few studies examined rivers of different size from small to large basins $[16,20,22,24,26,28]$. Smaller upstream gauges are important for trend analysis and attribution of found changes to natural drivers since impoundments and land cover change had a minimal effect on flow data from the small basins [29]. Smaller basins sometimes show opposite tendencies in comparison with large rivers $[26,30]$ showed that annual Vilyuy river streamflow has increased since the mid-1980s, but not all Vilyuy river tributaries have the same tendency. Knowledge gained at the small basins may be a clue to the understanding of processes on the larger scale. Analysis of changes on small basins is important for practical purposes since many settlements in cold regions are located along the rivers of different sizes and are exposed to floods and other river-related hazards.

The aim of this study is the estimation of long-term changes of monthly discharges of the 11 river catchments in the Aldan River basin in Eastern Siberia. We considered the dependence of trends on month, sample length, finish and start years, basin area and streamflow.

Although there were many studies made on trend assessment for the large Arctic rivers, there is, to our knowledge, no study dedicated particularly to the Aldan River basin, the largest Lena River tributary and the sixth largest river in Russia. The long-term discharge time series for the Aldan River and its tributaries starting as early as 1926 makes it interesting for studying the impact of period length and location in time.

\section{Study Object, Materials and Methods}

\subsection{Study Area}

Aldan River with the basin area 696,000 sq. $\mathrm{km}$ is tributary on the right side of the Lena River. It flows in the mountainous southeastern part of the Lena river basin and does not have significant flow regulation and other anthropogenic influence. Overall, 89\% of the basin is covered by continuous permafrost and $11 \%$ by discontinuous permafrost. Mean annual streamflow is $245 \mathrm{~mm}$ /year near the Aldan River outlet at the gauging station Verhoyansky Perevoz. Annual streamflow is between 101 and $477 \mathrm{~mm} /$ year within the 11 sub-basins studied in this paper. The smallest $(<10,000$ sq.. $\mathrm{km})$ and mountainous catchments have the highest streamflow, above $400 \mathrm{~mm} /$ year. Streamflow of the Amga river is less $200 \mathrm{~mm} /$ year due to dry climate and flat relief in the middle and low parts of the basin. Streamflow of the Aldan river varies from $340 \mathrm{~mm} /$ year in upper part to $245 \mathrm{~mm} /$ year at the river outlet. Anisimov et al. [31] assessed that air temperature increase in the Aldan River basin vary between 0.2 and $0.8^{\circ} \mathrm{C}$ per decade for the period 1976-2018. Changes in total precipitation are insignificant in winter and are mainly positive for the other seasons.

\subsection{Datasets}

We chose 11 gauges in the Aldan river basin with available long-term streamflow data from river gauging stations operated by the Russian hydrological service (Roshydromet) (Figure 1). Analyzed monthly discharge series are shown at Figure 2. The median length of the full observation series is 79 years with minimum and maximum values reaching 69 and 92 years, respectively. Few randomly distributed gaps (less 1\% of the full dataset) were filled based on strongest regression with other gauges in the dataset. Area of the river basins ranges between 613 and 696,000 sq. km with the median 49,500 sq. km. Minimum, 
median and maximum mean annual discharges are 9.3, 199 and 5408 cubic m/s, mean annual runoff depth—100, 268 and $477 \mathrm{~mm} /$ year.

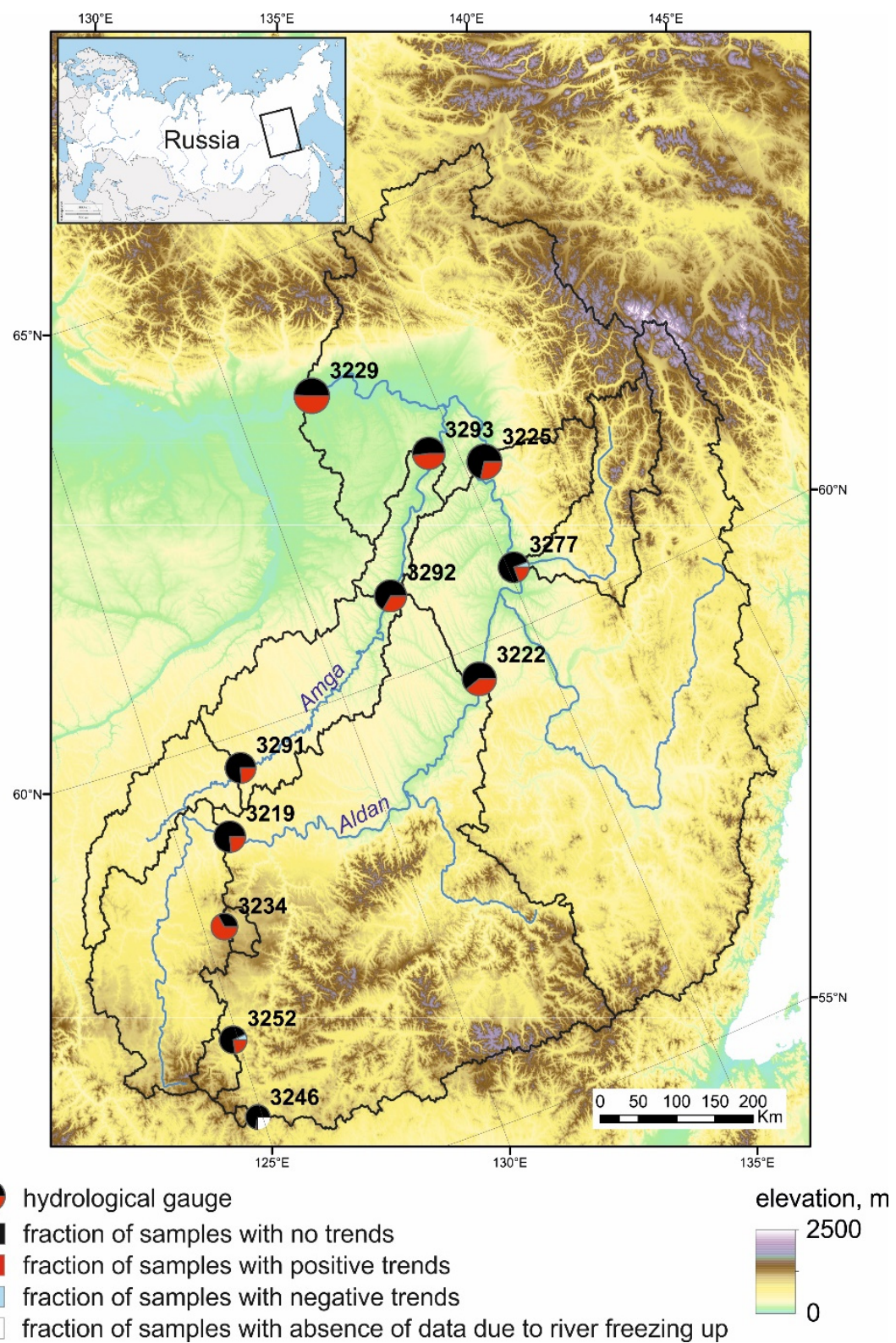

Figure 1. Scheme of the studied area: Aldan river basin and analyzed subbasins, fraction of the samples with positive, negative, no trends and no data. Size of the circles is proportional to the basin area. 


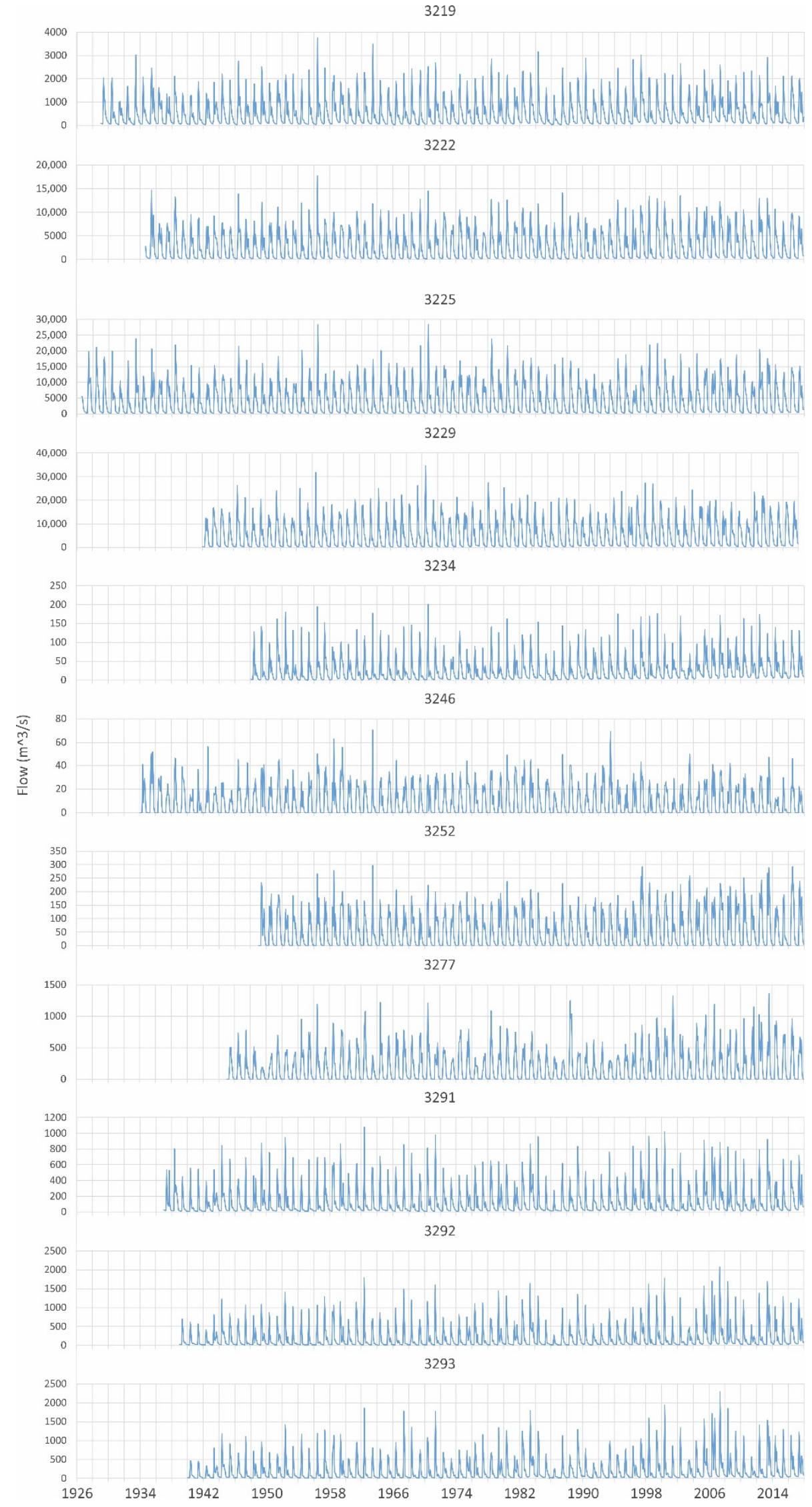

Figure 2. Monthly discharge series of the 11 studied gauges $\left(\mathrm{m}^{3} / \mathrm{s}\right)$. 


\subsection{Methods}

For each river gauge, we sampled multiple time series of monthly water discharges with a duration of 40, 45, 50, 55, 60, 65, 70, 75, 80, 85 and 90 years from the full available data series. This procedure resulted in samples of different durations starting from all possible years in the dataset. In total, 23,724 samples were analyzed for 11 gauges (Table 1).

Table 1. Basic characteristics of river basins (ID, name, area, data period, mean annual discharge (D), mean annual runoff depth (R), maximum monthly D and corresponding month, min monthly D and corresponding month, number of analyzed samples).

\begin{tabular}{|c|c|c|c|c|c|c|c|c|}
\hline ID & River-Gauge & $\begin{array}{l}\text { Basin Area, } \\
\text { sq.km }\end{array}$ & $\begin{array}{l}\text { Data } \\
\text { Period }\end{array}$ & $\begin{array}{c}\text { Mean } \\
\text { Annual D, } \\
\mathrm{m}^{3} / \mathrm{s}\end{array}$ & $\begin{array}{c}\text { Mean } \\
\text { Annual R, } \\
\text { mm }\end{array}$ & $\begin{array}{l}\text { Max Month D, } \\
\mathrm{m}^{3} / \mathrm{s} \text {, Month }\end{array}$ & $\begin{array}{l}\text { Min Month D, } \\
\mathrm{m}^{3} / \mathrm{s} \text {, Month }\end{array}$ & $\begin{array}{l}\text { No of } \\
\text { Samples }\end{array}$ \\
\hline 3219 & Aldan at Tommot & 49,500 & 88 & 536 & 342 & 1849, May & 71.1, March & 3180 \\
\hline 3222 & Aldan at Ust'-Mil' & 269,000 & 84 & 2852 & 334 & 8956, June & 203, March & 2484 \\
\hline 3225 & $\begin{array}{c}\text { Aldan at Okhotsky } \\
\text { Perevoz } \\
\text { Aldan at }\end{array}$ & 514,000 & 92 & 4362 & 268 & 15,132 , June & 296, March & 3432 \\
\hline 3229 & $\begin{array}{c}\text { Verhoyansky } \\
\text { Perevoz }\end{array}$ & 696,000 & 76 & 5408 & 245 & 18,976 , June & 351, April & 1776 \\
\hline 3234 & $\begin{array}{l}\text { Ulakhan-Nymnyr } \\
\text { at Bolshoy Nimnyr }\end{array}$ & 1900 & 70 & 26.9 & 447 & 95.2, May & 3.3, February & 1260 \\
\hline 3246 & $\begin{array}{l}\text { Timpton at } \\
\text { Nagorny }\end{array}$ & 613 & 84 & 9.3 & 477 & 23.7, June & 0, Dec.-Mar. & 2592 \\
\hline 3252 & $\begin{array}{l}\text { Chulman at } \\
\text { Chulman }\end{array}$ & 3840 & 69 & 53.8 & 442 & 156, May & 0, March & 1188 \\
\hline 3277 & $\begin{array}{l}\text { Allakh-Yun' at } \\
\text { Allakh }\end{array}$ & 24,200 & 73 & 18 & 243 & 585, June & 0.7, March & 1512 \\
\hline 3291 & Amga at Buyaga & 23,900 & 81 & 128 & 169 & 645, May & 16.1, March & 2268 \\
\hline 3292 & Amga at Amga & 56,800 & 79 & 199 & 111 & 1009, May & 20.6, March & 2064 \\
\hline 3293 & Amga at Teryut' & 65,400 & 78 & 210 & 101 & 980, May & 24.3, March & 1968 \\
\hline
\end{tabular}

Time series were evaluated for stationarity in relation to the presence of monotonic trends with Mann-Kendall and Spearman rank correlation tests at the significance level of $p<0.05$ [32-34]. If both tests suggested a trend at the significance level $p<0.05$, a serial correlation coefficient was tested at unity lag $\mathrm{r}$. With the serial correlation coefficient $\mathrm{r}<0.20$, the trend was considered reliable. In the case of $r>20$, to eliminate serial correlation in the input series the "trend-free pre-whitening" procedure (TFPW), described by Yue et al. [35], was carried out. Other hydrological trend detection studies followed the same TFPW procedure [2,36]. "Whitened" time series were repeatedly tested with a Mann-Kendall nonparametric test and those with $p \leq 0.05$ were counted significant.

For every gauge, we got a pattern of trends based on multiple trend analysis with different sample length, and different beginning and ending years. The variable length, beginning and ending years approach was successfully applied in trend studies of snowmelt timing [37], streamflow pattern [38], and Arctic precipitation and streamflow trends [9]. This type of analysis provides a more robust representation of change given the sensitivity of trend estimates to the choice of start and end years [17].

\section{Results}

\subsection{Trends Dependence on Month, Sample Length, Finish and Start Years}

Longer sampling periods tend to show more positive trends than shorter ones (Figure 3). More than $70 \%$ of the 40 -year samples do not have any trends and only $20 \%$ have statistically significant positive trends. For 65 -year samples, the fraction of no trend is $55 \%$, and the fraction of positive trends is $40 \%$. The 75 -year samples have slightly higher fractions of positive trends comparative to the absence of them. Approximately $60 \%$ of the 85 -year and 90 -year samples have positive trends, and only $35-40 \%$ of them do not show any trend. 


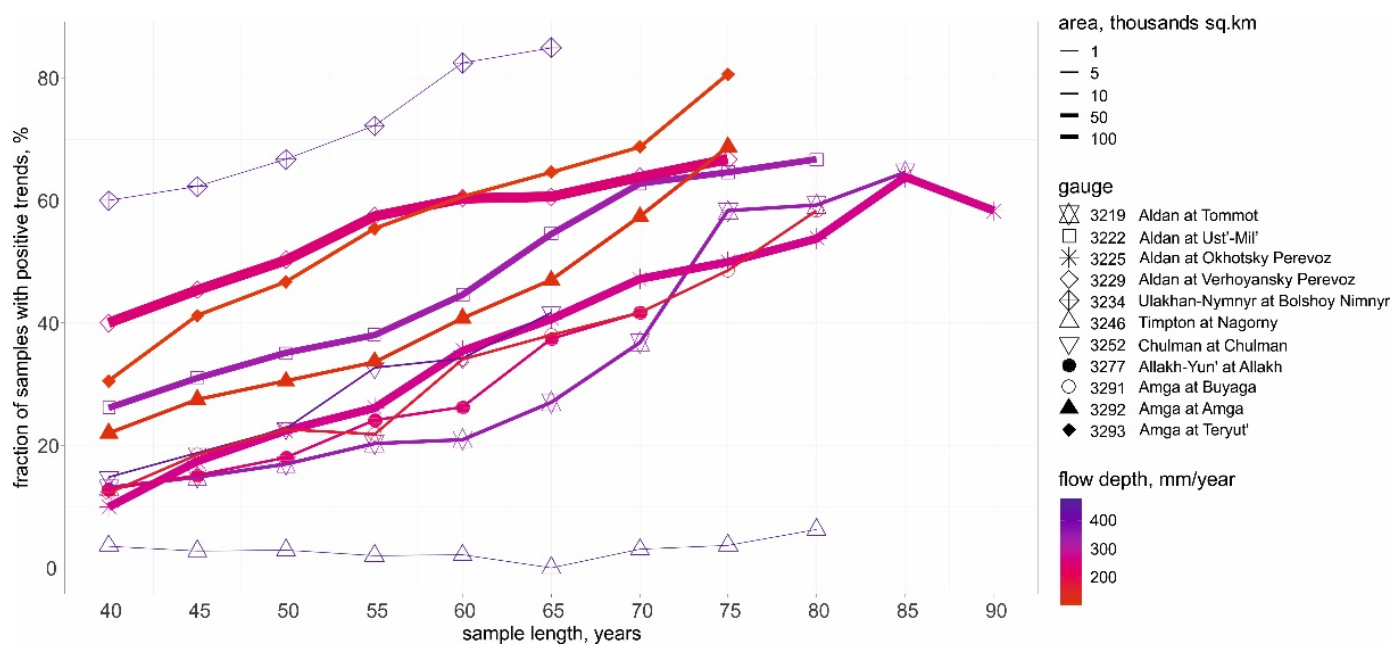

Figure 3. Fraction of samples with positive trends for every gauge for different sample lengths.

The increasing fraction of series with positive trends as a function of sample length is characteristic for every gauge, except for Timpton R. at Nagorny (ID 3246), which has a fraction of samples with positive trends between 0 and $6.3 \%$ regardless of sample length. At Ulakhan-Nymnyr R. at Bolshoy Nimnyr (ID 3234), the fraction of samples with positive trend rises from 60 to $85 \%$ with sample lengthening from 40 to 65 years. At other gauges, it increases from $10-40 \%$ to $40-80 \%$ with sample length increasing from 40 to $65-90$ years.

In most gauges, the identified trends have a prominent seasonality (Figure 4 ). June discharges do not increase at any gauge. Additionally, 10\% or less of all analyzed samples show positive trends in July, August and September. Upper Aldan (ID 3219, 3222) and Timpton (ID 3246) rivers show small number of positive trends in July (4-7\%) followed by their absence in August. Chulman (ID 3252) and Amga (ID 3291, 3292, 3293) rivers have more positive trends in August (11-34\%) than in July (5-29\%). September streamflow is relatively stable at the Amga (ID 3291, 3292, 3293) and Aldan (ID 3219, 3222, 3225, 3229) rivers ( $<6 \%$ of samples with positive trends), but increases at the $39-51 \%$ of samples at the Chulman (ID 3252), Allakh-Yun' (ID 3277) and Ulakhan-Nymnyr (ID 3234) rivers.

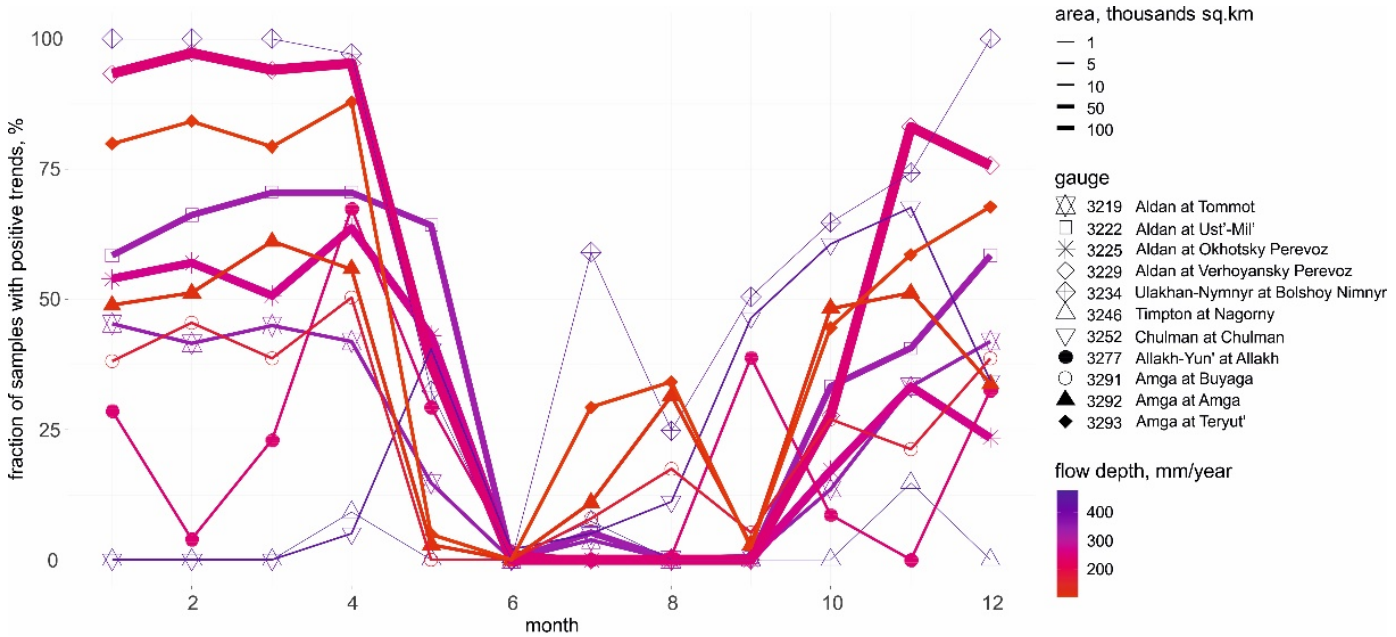

Figure 4. Fraction of samples with positive trends at the studied gauges for different months.

Within all analyzed samples, there is growing fraction of positive trends from October to April from 31 to 59\%. The Aldan, Amga and Ulakhan-Nymnyr rivers support the tendency of growing fraction of positive trends in October-April. On top of this general tendency, the lower Aldan and middle Amga rivers have a small reduction of samples with 
positive trends between November and December, upper Amga-between October and November. Chulman, Allakh-Yun' and Timpton rivers have different seasonality in the found trends in autumn and winter: after high fractions of samples with positive trends in October (61\%) and November (68\%) Chulman river does not show any streamflow changes in January, February and March. Timpton River, the only river that freezes up to the bottom in winter, have streamflow increase at the $15 \%$ and $9 \%$ of samples in November and April, respectively. Allakh-Yun' river has an uneven pattern of fraction of samples with positive trends during the autumn and winter.

There is a clear tendency of an increasing fraction of samples with positive trends with later end year (Figure 5). Samples finishing before 1977 do not show any positive trends except in the Aldan River at Okhotsky Perevoz (ID 3225). Samples finishing in 1978 and later show growing fractions of positive trends. Before 1983, a high fraction of samples with positive trends mostly relates to Aldan River at Okhotsky Perevoz. Within samples finishing in 1984-1986, Aldan at Verhoyansky Perevoz (ID 3229), Amga at Teryut' (ID 3293) and Allakh-Yun' River at Allakh (ID 3277) also show positive trends (16-50\% of samples). Amga at Teryut', Aldan at Verhoyansky Perevoz and at Okhotsky Perevoz show cycles on the top of growing fraction of samples with positive trends with later end year. Allakh-Yun' River has cycles on the top of declining fraction of samples with positive trends with later end year. It gradually grows at the Ulakhan-Nymnyr R. (ID 3234), Chulman (ID 3252), Amga at Buyaga (ID 3291) and Amga (ID 3292), Aldan at Tommot (ID 3219) and Ust'-Mil' (ID 3222) without clear cycles. Cycles of trends could potentially be explained by cycles of streamflow in the initial data series. Over $40 \%$ of all analyzed samples, finishing after 2006, have a positive trend. Maximum fractions of samples with positive trends at different gauges reach $50 \%$ and more with end years in 2008-2016 except Allakh-Yun' (ID 3277) and Timpton (ID 3246) rivers. This fraction does not exceed 10\% at the Timpton River with any end year. The Allakh-Yun' river shows more positive trends in samples ending in 1984-1986 than in later years. The highest fraction of positively changing samples is found at the Ulakhan-Nymnyr R. (ID 3234). It gradually increases from $33 \%$ (end years 1987-1989) to $87.5 \%$ (end years 2013-2015).

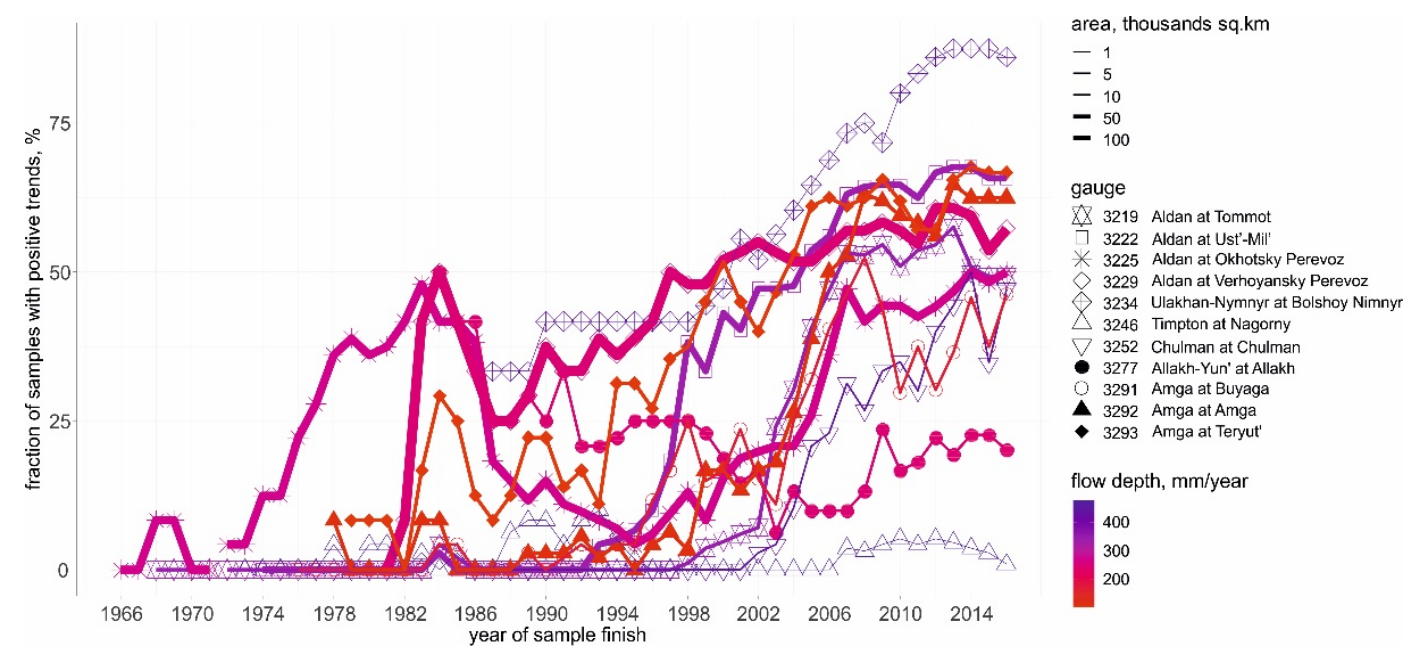

Figure 5. Fraction of samples with positive trends at the studied gauges for different ending years.

At lower Aldan and Amga rivers, the increasing fraction of samples with positive trends happens earlier than at the upper parts of the same rivers. The results suggest that the larger rivers are more sensitive to changes than smaller ones.

Samples starting in different years (Figure 6) do not show any single pattern. Among all samples those beginning in 1960-1968 have higher fraction of positive trends (>40\%). There is some decrease of no trend fraction from 1930 to 1975. Separate gauges have different patterns depending on beginning year. Chulman (ID 3252), Ulakhan-Nymnyr 
(ID 3234) rivers and Aldan at Ust'-Mil' (ID 3222) show a more positive trend towards later year of sample start. Aldan at Okhotsky Perevoz (ID 3225) and Allakh-Yun' (ID 3277) have more positive trends in samples starting in earlier years. Many other rivers (Aldan at Tommot (ID 3219), Aldan at Verhoyansky Perevoz (ID 3229) and all three gauges on the Amga river (ID 3291, 3292, 3293)) have maximum fraction of samples with positive trends within samples beginning between 1959 and 1971.

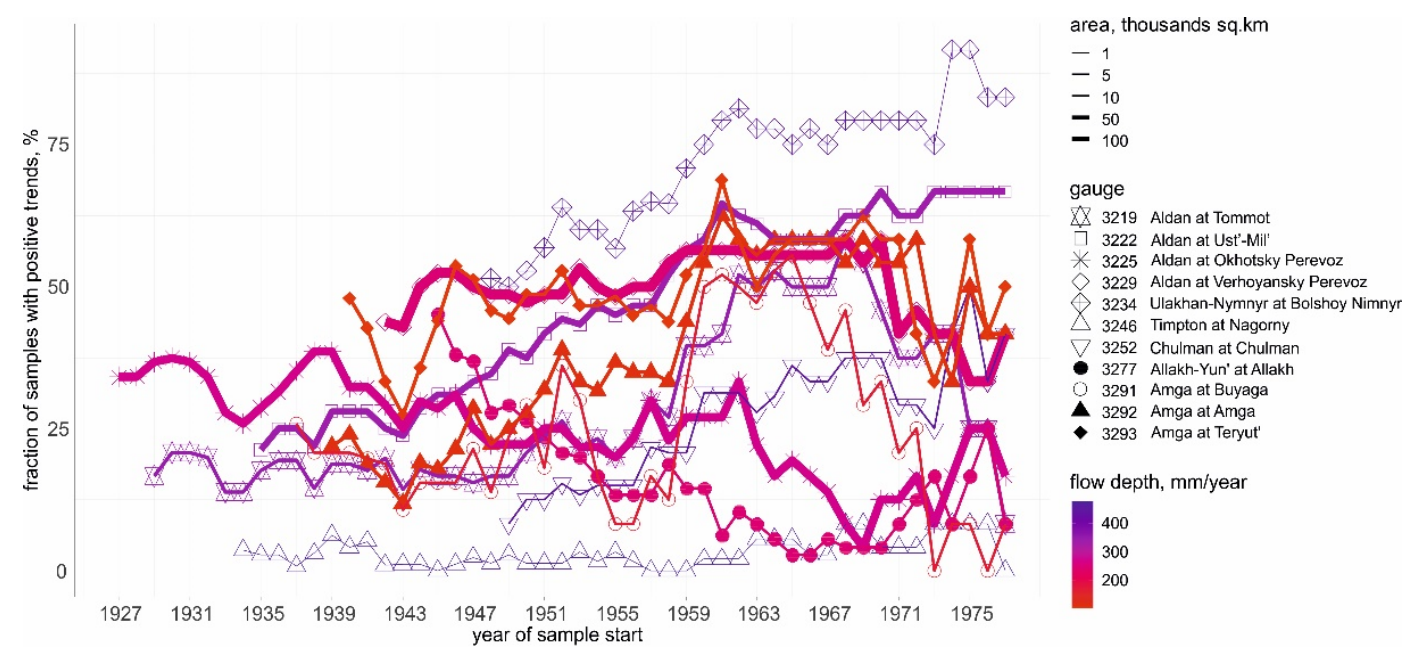

Figure 6. Fraction of samples with positive trends at the studied gauges for different beginning years.

\subsection{Trends at the Separate Gauges}

Totally the median fraction of samples with no trend is $70.5 \%$, with positive trends-28.5\% in the dataset. Fraction of the samples with positive, negative and no trends for every gauge is shown at Figure 1. Except for the Ulakhaan-Nimnyr River, there is positive correlation between the fraction of positive trends and the basin area, which is most pronounced in winter months, from December till April. The larger river basin, the higher fraction of samples with upward trends. Only two relatively small rivers-Chulman at Chulman and Allakh-Yun' at Allakh—show distinguishing fraction of negative trends.

Hydrological change patterns at the studied gauges differ (Figure 7). Timpton at Nagorny (ID 3246) shows changes at the lowest fraction of samples comparative to other gauges - only at $3 \%$ of the samples. It is the smallest river basin in the dataset with an area of 613 sq. km and freezes up to the bottom every winter. Most of the found changes occur in April, July and November in samples starting in 1963-1976 and finishing in 1988-1994 and 2009-2013. May, August, October have no trends. September and December have few negative trends. April and December could be biased since in many years the river is frozen up to the bottom during those months. In January, February and March the river is frozen up to the bottom every year.

The second smallest river basin, Ulakhaan-Nimnyr at Bolshoy Nimnyr (ID 3234, 1900 sq.km), in opposite, shows the highest fraction of positive trends- $67 \%$. From December till April all samples show positive trends regardless of sample length, beginning and end year. There are three exceptions in April corresponding to 40 years long time series starting in 1948-1951 and ending in 1988-1990. On other months except June, positive trends are found in samples finishing after 2000-2010. There are no positive trends in June but one negative that could suggest flattening of the river hydrograph.

The outlets of the two largest rivers in the dataset, the Aldan at Verhoyansky Perevoz (ID 3229, 696,000 sq.km) and Amga at Teryut' (ID 3293, 65,400 sq.km) have approximately equal fractions of positive trends and no trend. All other rivers (except for described earlier Timpton and Ulakhaan-Nimnyr) have between 19 and 39\% samples with positive trends. 

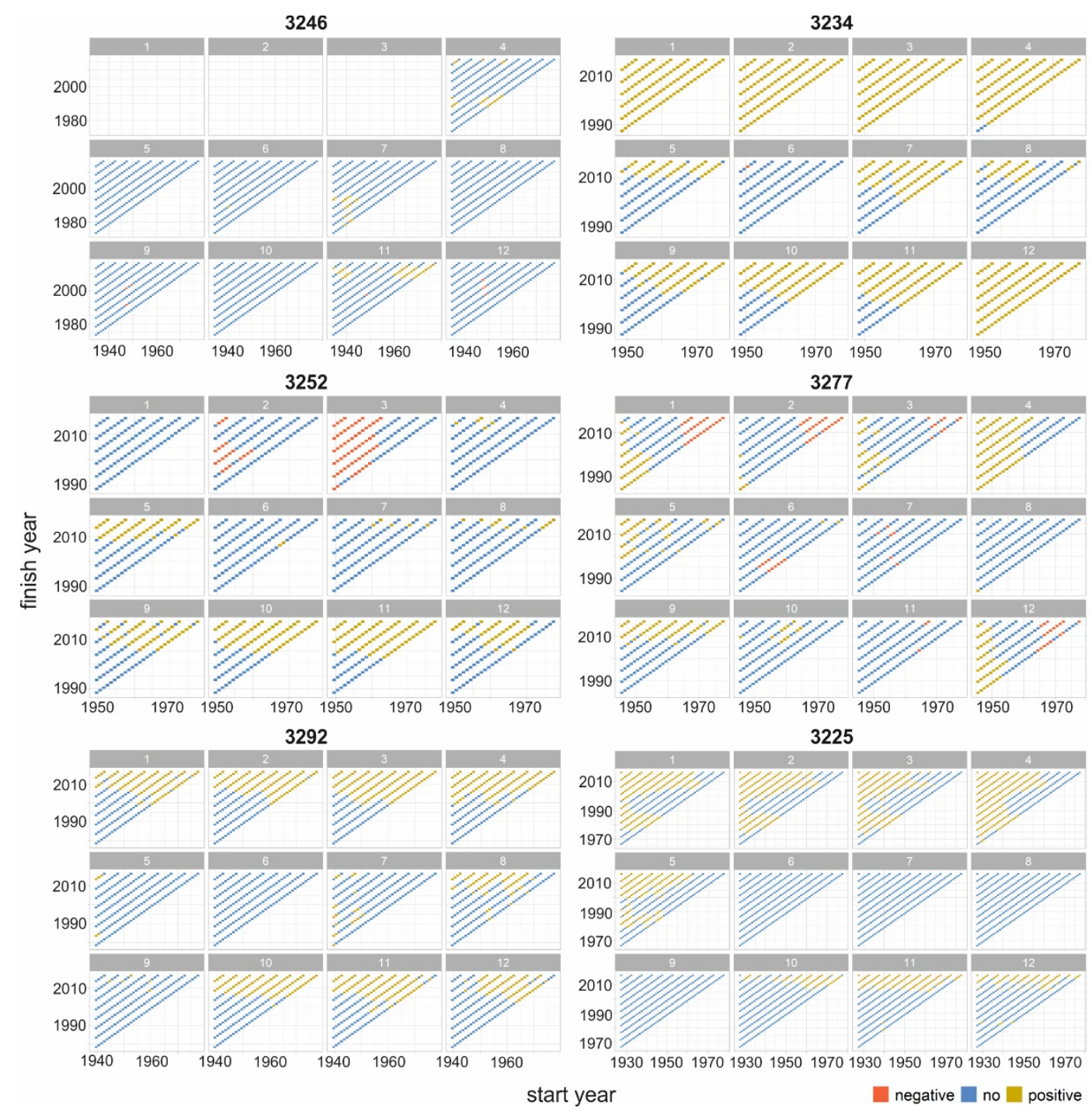

Figure 7. Trend patterns for different months, start and finish years for Timpton at Nagorny (3246), Ulakhan-Nymnyr at Bolshoy Nimnyr (3234), Chulman at Chulman (3252), Allakh-Yun' River at Allakh (3277), Amga at Amga (3292) and Aldan at Okhotsky Perevoz (3225).

At the four gauges on the Aldan River, summer flow (June, July, August and September) have only occasional (less 6\%) positive or negative trends regardless of sample length. Summer (including September) is the most stable period at all four gauges on the Aldan river. Few positive trends are found in July in long ( $>60$ years) samples covering years after 2000. More than $40 \%$ of January, February, March and April samples show positive trends. Samples with positive trends mostly cover periods after 2000. Fraction of samples with positive trend increase from September to December on the Aldan River. The largest Aldan river basin at Verhoyansky Perevoz have higher total fraction of positive trends (50.3\%) than nested Aldan watersheds. Over 90\% of January, February, March and April samples at Verhoyansky Perevoz show positive trends comparative with $41-71 \%$ at the upper gauges on the Aldan River. Since all other studied rivers eventually flow to the Aldan River, change at Verhoyansky Perevoz could be considered as an overall indicator of change in the whole basin.

Chulman River at Chulman (ID 3252) and Allakh-Yun' River at Allakh (ID 3277) are two gauges where negative trends in winter months have relatively high fraction-more than $6 \%$. It contrasts with other gauges that show increase of winter streamflow. 
Negative trends in the Chulman river are mainly found in March and February, especially in samples that start before 1960. In some years, the Chulman river freezes up to the bottom in February, March and April. Samples, finishing in 2005-2010 and later, show many positive trends in May (40.4\%), September (46.5\%), October (60.6\%), November $(67.7 \%)$ and December $(34.3 \%)$ that could indicate earlier onset and later river freezing.

For Allakh-Yun' River at Allakh (ID 3277) samples of December, January, February and March starting after 1965 show negative trends. Interestingly those months have positive trends in some samples starting before 1955 that could be explained by cycles of streamflow. Additionally, $67.5 \%$ of April samples have positive trends that could reflect earlier spring onset. Most of them start before 1960. September discharge is increasing in samples finishing after 2010.

On the Amga river the downstream gauges have more positive trends in all months, except September, than upstream gauges. June does not show any statistically significant trends at all three gauges. Only small fraction $(<6 \%)$ of May and September samples show positive trends. Some July samples starting between 1945 and 1950 show positive trends. August, October, November, December, January, February, March and April have similar pattern of positive trend distribution on the samples and their increasing fraction from upstream to downstream of the Amga River. Discharge increases mostly in samples finishing after 2000-2010 at Buyaga (ID 3291), Amga (ID 3292) gauges, and after 1990-2000 at Teryut' (ID 3293) gauge.

\section{Discussion}

The identified changes in monthly discharges of the Aldan river and its tributaries mainly agree with the earlier studies of changes in the regional hydrology [24] and complement previous research with new results on the dependence of change on season, sample length, beginning and finishing year for small, medium and large river basins.

Presence and absence of trends greatly depend on the analyzed data period. Longer samples tend to show more positive trends than shorter ones at all studied catchments in the Aldan river basin except the smallest one, Timpton river watershed. Ahmed et al. [15] found larger rise (14\%) of the combined annual discharge from the four largest Arctic-draining rivers (including the Lena River) during the 30 years long period than Peterson et al. [7] who reported the $7 \%$ increase using 60 years long records from the six largest Eurasian rivers. Peterson et al. [7] used data before 2000 only while Ahmed et al. [15] assessed more recent changes between 1980 and 2009. It suggests greater change during the more recent period of analysis that agrees well with increasing fraction of samples with positive trends with later end year found in the Aldan river basin. Adam and Lettenmaier [9] also demonstrated that the longest periods with significant trends have been positive, and the largest positive trends occurred during the later part of the record of the three largest Eurasian rivers over 1936-2000. The revealed widespread positive changes in streamflow records covering years after 2000 in the Aldan river basin updates the existing conclusion that streamflow increases accelerated up until the end of the last century [9]. Shiklomanov and Lammers [25] noted that the flow of the Arctic Eurasian rivers in 2007 was unusually high and it was not an aberration, but a part of the general hydroclimatic trends since 1980. It altogether agrees with Berezovskaya et al. [22], who showed that Aldan River experienced an extended low water period in the first part of the century (1936-1957), which was followed by the wet periods of 1974-1983 and 1988-2001 in the latter part of the last century.

Analyzed gauges in the Aldan river basin demonstrate prominent seasonality of the identified trends. In the contrast to Ahmed et al. [15], who documented the greatest streamflow increase in fall compared to other seasons, we found growing fraction of positive trends from October to April in the Aldan river basin. It agrees well with Ye et al. [23], who revealed a discharge increase in the Aldan basin from November till May over the period 1942-1999, weak increases during the high-flow season and a decreasing trend in August. Our results showed that summer (including September) is the most stable 
season for the Aldan river that does not show many trends regardless of sample length and coverage. Rawlins et al. [17] found the positive trends in winter and the negative trends over the most recent decades in summer/fall discharge of the three largest Eurasian basins (the Ob, Yenisei, and Lena) including a negative trend of spring flow (April, May, June) for Aldan at Ust'-Mil and Aldan at Verkhoyanskiy Perevoz. We found occasional negative trends in June and many positive trends in April in the Aldan river streamflow that supports the commonly discussed tendency of snowmelt shifting to earlier dates and spring flood flattening.

Anisimov et al. [31] assessed that air temperature growth in the Aldan River basin vary between 0.2 and $0.8^{\circ} \mathrm{C}$ per decade for the period 1976-2018. For the 1976-2020 air temperature increases from 0.4 to $0.7^{\circ} \mathrm{C}$ per decade [39] with the highest increase in the flat north-west of the basin and lower change in mountainous southern and north-eastern parts. Within the year winter and summer changes are moderate while air temperature intensively rises in autumn and spring. It means that dates of air temperature transition between positive and negative values shift to earlier time in spring and later periods in autumn, that implies more rain instead of snow in autumn and earlier snowmelt in spring. It could explain the high fraction of positive trends of flow in April, when temperature shifts to positive values, and in October and following winter months, when additional water comes as a rain and forms a higher basis of the winter recession curve. A similar shift in the rain-snow ratio in the Yana and Indigirka River basins leads to positive trends in monthly streamflow during the autumn-winter [19]. It agrees with the found significant decreasing trend of the contribution of snowmelt water to the total streamflow of the headwaters of the Yangtze, Yellow, and Lantsang rivers [40]. Changes in total precipitation in the Aldan river basin are insignificant in winter and are mainly positive for the other seasons [31] with an increase of 5-10 mm per decade in autumn and spring [39] that contribute to the effect.

Many significant positive trends of streamflow in winter and a small amount of them in summer are typical for the contemporary hydrological changes in the Arctic, which is confirmed by our findings and previous works [17,21,23,41,42].

While the broad-scale pattern of hydrological changes in the Arctic is relatively well studied, regional- and local-scale patterns are not described [20]. Our results highlight a variety of responses of small, medium and large rivers to climate changes. The larger river basins have the higher fraction of samples with the upward trends in the Aldan river basin. The higher total fraction of positive trends, including earlier years, in the lower Amga and Aldan than in their upper parts confirm a general pattern of more pronounced changes in larger river basins and later occurrence of significant changes upstream. Small basins show contrast tendencies of hydrological changes up to significant fractions of negative trends, while larger basins have a smoother pattern and generally agree with each other. In Canada, the streamflow in the Athabasca River Basin has been decreasing since 1960 and will likely increase in the mid-century [43] that indicates that even one-way climate change could influence streamflow of the river differently with time.

We showed complicated pattern of trend distribution through time and space. Comparison of trend results estimation for different sample lengths and coverage may lead to misinterpretation of the general pattern of hydrological change.

This study was limited to the characterization of trends and their distribution in time and space, and while the results are clearly in line with previous findings on air temperature and precipitation changes, it is not enough to fully understand and explain the identified streamflow change patterns. A possible way forward towards an increased understanding of these changes could include modelling analyses and exploration by data on other key hydrological components such as snow, permafrost and groundwater.

\section{Conclusions}

Within the 11 gauges on small, medium and large rivers in the Aldan river basin, the median fraction of samples with no trend, positive and negative trends are $70.5 \%, 28.5 \%$, 
and $1 \%$, respectively. The presence and absence of trends greatly depend on the length of the analyzed data period, with some variations between the different river gauges. Even 1-2 years' difference in the length and/or coverage of the analyzed series can change the result of the statistical test. Longer samples tend to show more positive trends than shorter ones. There is a clear tendency of increasing fraction of samples with positive trends as a function of later sample end year, whereas the sample start year do not result in a similar single pattern. On the contrary, there is a tendency that the fraction of positive trends is decreasing using later start year, especially in the larger rivers. The larger river basins, with one exception, have more positive trends than smaller ones. The identified trends in monthly streamflow have prominent seasonality with the absence of positive trends in June and increase in the positive trend fraction from October till April. Over half of all April samples show positive trends. For large Amga and Aldan rivers, the presence of positive trends prevails over negative ones, while both positive and negative trends are found in medium rivers.

Author Contributions: Conceptualization, L.L. and D.G.; methodology, L.L.; data analysis, L.L.; writing—original draft preparation, L.L.; writing—review and editing, D.G.; visualization, L.L.; funding acquisition, L.L. and D.G. All authors have read and agreed to the published version of the manuscript.

Funding: The analysis of winter river runoff was carried out with the financial support of the President of the Russian Federation Grant for young Russian scientists (project No. MK-5330.2021.1.5). The analysis of spring and summer river runoff was carried out with the financial support of the FORMAS (project DNR: 2019-02332), RFBR (project No. 20-55-71005) and JST (Grant No. JPMJBF2003) through the Belmont Forum Collaborative Research Action: Resilience in the Rapidly Changing Arctic, HYPE-ERAS project.

Institutional Review Board Statement: Not applicable.

Informed Consent Statement: Not applicable.

Data Availability Statement: Datasets after 2008 are publicly available. This data can be found here: https://gmvo.skniivh.ru/ (accessed on 20 August 2021). Restrictions apply to the availability of the data before 2008. Data before 2008 was obtained from the Russian Federal Service for Hydrometeorology and Environmental Monitoring (Rosgidromet) and are available from the authors with the permission of Rosgidromet.

Conflicts of Interest: The authors declare no conflict of interest.

\section{References}

1. Yang, D.; Shi, X.; Marsh, P. Variability and extreme of Mackenzie River daily discharge during 1973-2011. Quatern. Int. 2015, 380-381, 159-168. [CrossRef]

2. Bawden, A.; Linton, H.; Burn, D.; Prowse, T. A spatiotemporal analysis of hydrological trends and variability in the Athabasca River region, Canada. J. Hydrol. 2014, 509, 333-342. [CrossRef]

3. St. Jacques, J.-M.; Sauchyn, D.J. Increasing winter baseflow and mean annual streamflow from possible permafrost thawing in the Northwest Territories, Canada. Geophys. Res. Lett. 2009, 36, L01401. [CrossRef]

4. Déry, S.J.; Wood, E.F. Decreasing river discharge in northern Canada. Geophys. Res. Lett. 2005, 32, L10401. [CrossRef]

5. Déry, S.J.; Stadnyk, T.A.; MacDonald, M.K.; Gauli-Sharma, B. Recent trends and variability in river discharge across northern Canada. Hydrol. Earth Syst. Sci. 2016, 20, 4801-4818. [CrossRef]

6. Khaliq, M.N.; Ouarda, T.B.M.J.; Gachon, P.; Sushama, L.; St-Hilaire, A. Identification of hydrological trends in the presence of serial and cross correlations: A review of selected methods and their application to annual flow regimes of Canadian rivers. J. Hydrol. 2009, 368, 117-130. [CrossRef]

7. Peterson, B.J.; Holmes, R.M.; McClelland, J.W.; Vörösmarty, C.J.; Lammers, R.B.; Shiklomanov, A.I.; Shiklomanov, I.A.; Rahmstorf, C. Increasing river discharge to the Arctic Ocean. Science 2002, 298, 2171-2173. [CrossRef]

8. Shiklomanov, A.I.; Yakovleva, T.I.; Lammers, R.B.; Karasev, I.P.; Vorosmarty, C.J.; Linder, E. Cold region river discharge uncertainty-estimates from large Russian rivers. J. Hydrol. 2006, 326, 231-256. [CrossRef]

9. Adam, J.C.; Lettenmaier, D.P. Application of New Precipitation and Reconstructed Streamflow Products to Streamflow Trend Attribution in Northern Eurasia. J. Clim. 2008, 21, 1807-1828. [CrossRef] 
10. Frolova, N.L.; Magritskiy, D.V.; Kireyeva, M.B.; Agafonova, S.A.; Povalishnikova, Y.S. Antropogennyye i klimaticheski obuslovlennyye izmeneniya stoka vody i ledovykh yavleniy rek rossiyskoy Arktiki [Runoff and ice phenomena dynamics on the rivers of Russian Arctic due to anthropogenic and climate changes]. Voprosy geografii 2018, 145, 233-251.

11. Georgievskii, V.Y.; Ezhov, A.V.; Shalygin, A.L.; Shiklomanov, I.A.; Shiklomanov, A.I. Assessment of the effect of possible climate changes on hydrological regime and water resources of rivers in the former USSR. Russ. Meteorol. Hydrol. 1996, 11, 89-99.

12. Yang, D.; Ye, B.; Shiklomanov, A. Discharge characteristics and changes over the Ob River watershed in Siberia. J. Hydrometeorol. 2004, 5, 595-610. [CrossRef]

13. Yang, D.; Ye, B.; Kane, D.L. Streamflow changes over Siberian Yenisei River Basin. J. Hydrol. 2004, 296, 59-80. [CrossRef]

14. Yang, D.; Kane, D.L.; Hinzman, L.D.; Zhang, X.; Zhang, T.; Ye, H. Siberian Lena River hydrologic regime and recent change. J. Geophys. Res. 2002, 107, 4694. [CrossRef]

15. Ahmed, R.; Prowse, T.; Dibike, Y.; Bonsal, B.; O’Neil, H. Recent Trends in Freshwater Influx to the Arctic Ocean from Four Major Arctic-Draining Rivers. Water 2020, 12, 1189. [CrossRef]

16. Smith, L.C.; Pavelsky, T.M.; McDonald, G.M.; Shiklomanov, A.I.; Lammers, R.B. Rising minimum daily flows in northern Eurasian rivers: A growing influence of groundwater in the high-latitude hydrologic cycle. J. Geophys. Res. 2007, 112, G04S47. [CrossRef]

17. Rawlins, M.A.; Ye, H.; Yang, D.; Shiklomanov, A.; McDonald, K.C. Divergence in seasonal hydrology across northern Eurasia: Emerging trends and water cycle linkages. J. Geophys. Res. 2009, 114, D18119. [CrossRef]

18. Rennermalm, A.K.; Wood, E.F.; Troy, T.J. Observed changes in pan-arctic cold-season minimum monthly river discharge. Clim Dyn 2010, 35, 923-939. [CrossRef]

19. Makarieva, O.; Nesterova, N.; Post, D.A.; Sherstyukov, A.; Lebedeva, L. Warming temperatures are impacting the hydrometeorological regime of Russian rivers in the zone of continuous permafrost. Cryosphere 2019, 13, 1635-1659. [CrossRef]

20. Shiklomanov, A.I.; Lammers, R.B.; Lettenmaier, D.P.; Polischuk, Y.M.; Savichev, O.G.; Smith, L.C.; Chernokulsky, A.V. Hydrological Changes: Historical Analysis, Contemporary Status, and Future Projections. In Regional Environmental Changes in Siberia and Their Global Consequences; Groisman, P.Y., Gutman, G., Eds.; Springer Science+Business Media: Dordrecht, The Netherlands, 2013; pp. 111-154. [CrossRef]

21. Ye, B.; Yang, D.; Zhang, Z.; Kane, D.L. Variation of hydrological regime with permafrost coverage over Lena Basin in Siberia. J. Geophys. Res. 2009, 114, D07102. [CrossRef]

22. Berezovskaya, S.; Yang, D.; Hinzman, L. Long-term annual water balance of the Lena River. Glob. Planet. Chang. 2005, 48, 84-95. [CrossRef]

23. Ye, B.; Yang, D.; Kane, D. Changes in Lena River streamflow hydrology: Human impacts versus natural variations. Water Resour Res. 2003, 39, 1200. [CrossRef]

24. Tananaev, N.I.; Makarieva, O.M.; Lebedeva, L.S. Trends in annual and extreme flows in the Lena River basin, Northern Eurasia. Geophys. Res. Lett. 2016, 43, 764-772. [CrossRef]

25. Shiklomanov, A.I.; Lammers, R.B. Record Russian river discharge in 2007 and the limits of analysis. Environ. Res. Lett. 2009, 4, 045015. [CrossRef]

26. Yumina, N.M.; Tereshina, M.A. Mnogoletniye izmeneniya stoka rek basseyna Vilyuya [Estimating long-term changes of river runoff in the Viluy river basin]. Vestnik Moskovskogo Universiteta Seriya 5 Geografiya 2017, 6, 62-70.

27. Arrieta-Castro, M.; Donado-Rodríguez, A.; Acuña, G.J.; Canales, F.A.; Teegavarapu, R.S.V.; Kaźmierczak, B. Analysis of Streamflow Variability and Trends in the Meta River, Colombia. Water 2020, 12, 1451. [CrossRef]

28. Georgiadi, A.G.; Kashutina, Y.A. Mnogoletniye izmeneniya godovogo i sezonnogo stoka rek basseyna Leny [The features of long-term annual and seasonal runoff changes for Lena basin rivers]. Izvestiya Rossiiskoi Akademii Nauk Seriya Geograficheskaya 2014, 2, 71-83.

29. Shiklomanov, A.I.; Lammers, R.B.; Rawlins, M.A.; Smith, L.C.; Pavelsky, T.M. Temporal and spatial variations in maximum river discharge from a new Russian dataset. J. Geophys. Res. 2007, 112, G04S53. [CrossRef]

30. Rumyantseva, Y.V.; Shestakova, Y.N.; Muzhdaba, O.V. Dinamika vodnykh resursov rek Arkticheskoy zony Zapadnoy Sibiri [Dynamics of water resources of the rivers of the Arctic zone of Western Siberia]. Nauchnyy Vestnik Yamalo-Nenetskogo Avtonomnogo Okruga 2017, 3, 53-61.

31. Anisimov, O.A.; Zhil'tsova, E.L.; Shapovalova, K.O.; Ershova, A.A. Analysis of Climate Change Indicators. Part 1. Eastern Siberia. Russ. Meteorol. Hydrol. 2019, 44, 810-817. [CrossRef]

32. Mann, H.B. Nonparametric tests against trend. Econometrica 1945, 13, 245-259. [CrossRef]

33. Kendall, M. Rank Correlation Measures; Charles Griffin: London, UK, 1975.

34. Lehmann, E.L. Nonparametrics, Statistical Methods Based on Ranks; Holden-Day, Inc.: San Francisco, CA, USA, 1975.

35. Yue, S.; Pilon, P.; Cavadias, G. Power of the Mann-Kendall and Spearman's rho tests for detecting monotonic trends in hydrological series. J. Hydrol. 2002, 259, 254-271. [CrossRef]

36. Burn, D.; Abdul Aziz, O.; Pietroniro, A. A Comparison of Trends in Hydrological Variables for Two Watersheds in the Mackenzie River Basin. Can. Water Resour. J./Rev. Can. Ressour. Hydr. 2004, 29, 283-298. [CrossRef]

37. Semmens, K.A.; Ramage, J.M. Recent changes in spring snowmelt timing in the Yukon River basin detected by passive microwave satellite data. Cryosphere 2013, 7, 905-916. [CrossRef]

38. Zhang, Z.; Dehoff, A.D.; Pody, R.D. New approach to identify trend pattern of streamflows. J. Hydrol. Engin. 2010, 15, 244-248. [CrossRef] 
39. A Report on Climate Features on the Territory of the Russian Federation in 2020; Roshydromet: Moscow, Russia, 2021; 104p.

40. Li, S.; Liu, M.; Adam, J.C.; Pi, H.; Su, F.; Li, D.; Liu, Z.; Yao, Z. Contribution of Snow-Melt Water to the Streamflow over the Three-River Headwater Region, China. Remote Sens. 2021, 13, 1585. [CrossRef]

41. Shiklomanov, I.A. (Ed.) Water Resources of Russia and Their Use; Nauka: St. Petersburg, Russia, 2008. (In Russian)

42. Tan, A.; Adam, J.C.; Lettenmaier, D.P. Change in spring snowmelt timing in Eurasian Arctic rivers. J. Geophys. Res. 2011, 116, D03101. [CrossRef]

43. Ghaderpour, E.; Vujadinovic, T.; Hassan, Q.A. Application of the Least-Squares Wavelet software in hydrology: Athabasca River Basin. J. Hydrol. Reg. Stud. 2021, 36C, 100847. [CrossRef] 